\title{
Kernos
}

Revue internationale et pluridisciplinaire de religion grecque antique

$27 \mid 2014$

Varia

\section{Dedications to Double Deities}

Syncretism or simply syntax?

Jenny Wallensten

\section{Q OpenEdition}

1 Journals

\section{Electronic version}

URL: http://journals.openedition.org/kernos/2278

DOI: $10.4000 /$ kernos.2278

ISSN: 2034-7871

\section{Publisher}

Centre international d'étude de la religion grecque antique

\section{Printed version}

Date of publication: 1 November 2014

Number of pages: 159-176

ISBN: 978-2-87562-055-2

ISSN: 0776-3824

\section{Electronic reference}

Jenny Wallensten, «Dedications to Double Deities », Kernos [Online], 27 | 2014, Online since 01 October 2016, connection on 04 May 2019. URL : http://journals.openedition.org/kernos/2278 ; DOI : 10.4000/ kernos. 2278

This text was automatically generated on 4 May 2019.

Kernos 


\title{
Dedications to Double Deities
}

\author{
Syncretism or simply syntax?
}

Jenny Wallensten

\section{AUTHOR'S NOTE}

I wish to thank the participants in the Third International Martin P. Nilsson Workshop on Greek Religion, In Search of Syncretism, for their valuable comments during the discussions. I am especially grateful to Dr. Maria Mili and Prof. Robert Parker, who commented on the manuscript in previous stages. The comments of the anonymous Kernos reviewers considerably improved the article and I thank them sincerely.

\section{Composite deities and syncretism}

1 Among the myriads of deities represented in the Greek epigraphic corpus can be found what might be called composite or double deities. These can initially be divided into two basic categories: firstly, non-cross-cultural composites gods such as Hera Aphrodite of Sparta or Zeus Ares of Arcadia ${ }^{1}$ and secondly, "international" multi-cultural combinations such as for example Isis Aphrodite. ${ }^{2}$ The present article focuses on three Delian votive inscriptions honouring gods of the latter category, where deities of different cultures are combined. ${ }^{3}$ In one instance, more than two gods seem to be juxtaposed, and all three cases include not only divine names, but also cult epithets. These elaborate examples come from Hellenistic Delos and introduce the complex Astarte Palaistine Aphrodite Ourania, or Astarte Palaistine Aphrodite Ourania Epekoos, ${ }^{4}$ and the even more complicated divine hybrid Isis Soteira Astarte Aphrodite Euploia Epekoos, a goddess joined in worship to the male combination Eros Harpokrates Apollon. ${ }^{5}$ As might be expected, these deities have often been called syncretistic gods. Corinne Bonnet has for example named the Isis-Astarte-Aphrodite a "henotheistic and syncretistic divinity"' and Petra Pakkanen sees such combination gods as an introductory step in the process of syncretism; she refers to the phenomenon as a parallelization of gods. ${ }^{7}$ Other scholars 
speak of assimilation, identification or even simply a translation of gods of different cultures: these are three other terms often used within the complex of phenomena referred to as syncretism. In the present article I will discuss the three case inscriptions in the context of this terminology and try to deepen the understanding of the character of the composite divinities in question. Is the syncretistic quality of a god like Isis Soteira Astarte Aphrodite Euploia Epekoos as clear as a mere glance on the combination of divine names from different cultural spheres indicates?

In the field of ancient Greek religion, the much studied term syncretism has mostly (and justly) been treated as a problematic concept due to its lack of a clear definition. In an attempt to deal with this, at a 1971 symposium, Pierre Lévêque presented five kinds of syncretisms he identified within the religions of antiquity. ${ }^{8}$ This article became much quoted, if not always in agreement. For example, in 1993, the Centre International d'Étude de la Religion Grecque Antique organized a symposium on syncretism with an expressed goal of trying to define the concept more clearly. When the proceedings were published a year later, the introduction was in the main - on the explicit invitation of Lévêque - a pertinent critique of his previous classification, in which the majority of Lévêque's categories was questioned. ${ }^{9}$ What the editors A. Motte and V. Pirenne-Delforge however did retain for the definition of "true" syncretisms, was the criterion that the outcome of a meeting between two initially foreign ingredients, be they iconographical, conceptual or other, should be a new entity with distinctive characteristics. Motte and Pirenne-Delforge underlined that if a religious phenomenon were to qualify as a syncretism, the end product had to be something more than its constituent parts. ${ }^{10}$ Moreover, influential studies in Greek religion have underlined that syncretism is a process and should perhaps even be seen as a system of its own: this was Luther Martin's response to the scholarly exasperation expressed over the seemingly chaotic and unorganized world of Hellenistic and Roman religion. ${ }^{11}$ In the present study, Motte and Pirenne-Delforge's criteria are kept for the discussion of whether we automatically should refer to an Isis Astarte Aphrodite as a "syncretistic god".

\section{The three inscriptions}

\section{IDélos 1719}

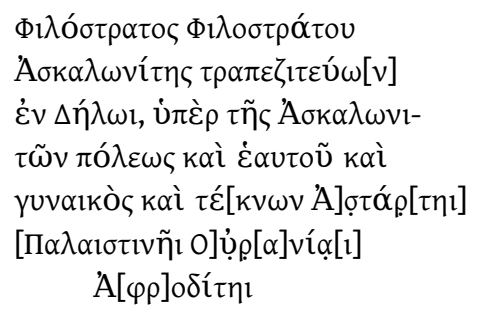

The first case inscription is IDélos 1719, carved on a round marble altar towards the end of the second century B.C.E. ${ }^{12}$ The altar was dedicated to Astarte Palaistine Ourania Aphrodite, by Philostratos, son of Philostratos from Ascalon, ${ }^{13}$ working as a banker in Delos, for the benefit of the polis of the Ascalonites, himself, his wife and children. The name of the recipient deity is somewhat restored, but safely so against the background of the second case inscription, IDélos 2305. It can be noted that the epithet Ourania stands before the name of the Greek deity, Aphrodite. ${ }^{14}$ 


\section{IDélos 2305}

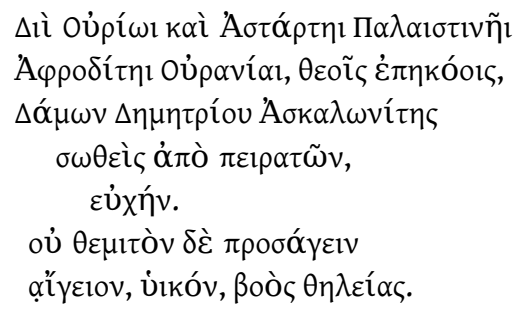

Through this votive inscription, another man of Ascalon, Damon son of Demetrios, presents a dedication to Zeus Ourios (Zeus of the Fair Wind) ${ }^{15}$ and Astarte Palaistine Aphrodite Ourania, theoi epekooi. ${ }^{16}$ It is indeed fortunate that two inscriptions naming this goddess have been found, not only because of the restoration of the missing word Palaistine, but also because of the clearly readable kai in IDélos 2305. Without this kai, it would be more or less impossible to identify Astarte Aphrodite as a single deity ${ }^{17} \mathrm{Her}$ name might just as well be read as two separate recipient deities: Astarte Palaistine and Aphrodite Ourania. (This mistake that was actually done in the first publication of the inscription. $)^{18}$ In other similar cases, when neither the wording, nor the epigraphic layout or our previous knowledge of Greek religion offers further clues, this can clearly become an editorial problem..$^{19}$ In the cases examined here, however, the inserted and between the male and female god certainly indicates that we should understand Astarte-Aphrodite as one goddess, and not two distinct deities. Moreover, the placing of kai as actually defining this juxtaposition of goddesses as a single recipient deity (at least in the Delian cases at hand) is further corroborated by the third case study examined for this paper. This is a votive inscription carved on a marble base and presented by Andromachos, son of Phanomachos, to Isis Soteira Astarte Aphrodite Euploia Epekoos and Eros Harpokrates Apollon (IDélos 2132). ${ }^{20}$

\section{IDélos 2132}

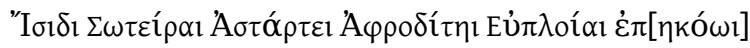

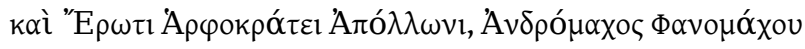

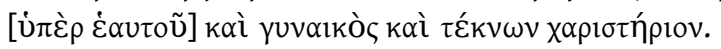

5 The exact date of the inscription is not known, but a terminum post quem of 166 or rather 140 B.C.E. has been given by Mora, who furthermore tentatively identifies the dedicator Andromachos Phanomachou with an Andromachos of Antiocheia, and as the father of another Andromachos active in Delos, who is known for contributions to the sanctuary of the Syrian goddess. ${ }^{21}$ The placing of the kai as a divider is clearly not fortuitous: it creates a divine pair as recipient deities. It can thus be established that an analysis of these deities is possible, since they are in fact composites, and not simply the result of the epigraphical editing process.

\section{Association and assimilation}

Quite a lot of examples where two gods from originally different cultures are combined can be brought forth. Isis Aphrodite and Isis Demeter could be named and perhaps even more famously Zeus Ammon. ${ }^{22}$ Two terms that often figure in connection with these double gods are association and assimilation. The term association is hardly ever defined, 
but appears to be the more vague concept of the two. In the context of Greek religion it is usually taken to mean the approaching of one deity to another, or, for that matter, of a mortal to a deity. Deities are associated through the iconographic use of the other deity's attributes, through shared temples or perhaps iconographic physical proximity such as statuary juxtapositions. Association is thus a term that is fairly safe to use, since it does not indicate an interpretative result but rather states the obvious. It can for example be safely said that in this paper's three case inscriptions, Astarte is associated with Aphrodite, and Isis with both these deities, physically on the stone and somehow in the mind of the dedicators. But this does not take us very far in terms of understanding the composites. Why are these gods associated? Why especially these gods and not others, and fundamentally, what is the result of the association?

7 Association is usually seen as a precursor of "real" syncretism. Assimilation, on the other hand, is a word that does point to a result, an end product such as a syncretism, since it can amount to full identification. A double divinity such as Isis Aphrodite or a combination mortal-immortal like Arsinoë Aphrodite can no longer be easily separated into "components", be they mortal or immortal, but is treated like a single recipient deity. ${ }^{23}$ But what does this mean in practice? The appearance of a wholly new god, celebrated through new rituals, with new priesthoods, with a new iconography? It is important to stress that in the concept of assimilation should be understood that one of the constituent parts is assimilated to, or into, the other, or that they together are assimilated into each other. If we accept this, then at least two basic outcomes are imaginable. The first is that two gods are assimilated into each other and become a distinct divine complex, which then would amount to a new, syncretistic, god: an end product that is something more than its constituent parts, as proposed by Motte and Pirenne-Delforge, or, in Assmann's words, a "merging which coexists with the original distinct entities". ${ }^{24}$ Isis Aphrodite could be taken as example. Worship of Isis Aphrodite as one distinct deity is attested on several occasions and in a variety of geographical contexts. Besides dedications, a priesthood attached to the cult of Isis Aphrodite is probably attested in Perinthos. ${ }^{25}$ In this case, we can furthermore suggest something about the character of the double goddess. The two original goddesses have an obvious meeting point in their respective marine aspects, and it appears that this common denominator became the main characteristic of the combination Isis Aphrodite, whose worship significantly is attested on islands and in cities with important ports. ${ }^{26}$ Each goddess here contributes with her maritime competence, and thus, through accumulation, this new deity becomes a more specialized god then the original constituent parts. ${ }^{27}$ The consequence of such a "mutual" assimilation, i.e., when two gods are assimilated into each other, would then in fact be a new deity, certainly so when this double god is offered worship repeatedly. It should be stressed that the result of such a syncretism is not that all outlines between the components Isis and Aphrodite are dissolved, although the new god is treated as a single recipient deity. The goddesses' two separate identities still exist, but made transparent to allow the new syncretistic god to take centre stage. ${ }^{28}$

8 There is however another possible outcome of assimilation, namely that one of the combined gods becomes the other, who thus retains an original identity, but is enriched by the identity of the first. This could be compared with one kind of what Robert Parker has called internal, that is, intra-Greek syncretism, where a major and a minor deity are combined. The mightier god enfolds the other, and keeps his or her name as new epithet. 
${ }^{29}$ The result of the assimilation is in this instance not a new god, but rather a new version of an old one. These terminological questions are of importance in the present context for two reasons. Firstly, because assimilation is often used as a synonym to syncretism, which is problematic if we keep the definition stating that the result of a syncretistic process is a combination of two parts that create a new entity (not necessarily a stable one, but at least temporarily something new). And secondly, in the case of the composites discussed in this article, because it can be questioned whether we really should call the juxtapositions of the three inscriptions assimilations and thereby, possibly syncretisms.

\section{Translated gods?}

With this discussion in mind I return to the three case studies. Above, it was established that we are indeed dealing with single integral recipient deities and not several separate gods. This makes it possible and indeed interesting to attempt an analysis of their characters. Furthermore, with the idea of a third deity being created by two (or more) foreign elements, the suggestion of assimilation and new syncretistic gods appears almost naturally. However, there is yet another possibility that needs to be considered, namely that the respective gods are translations of one another. The custom of translating divine names was practiced in the Mediterranean world in various ways and contexts since the third millennium B.C.E., as explored by E. Bikerman in the 1930s, and more recently, by amongst others, J. Assmann, M. Smith and G. Fowden..$^{30}$ Especially Assmann argues that the possibility of international or intercultural translation of gods was at the heart of ancient polytheistic societies, and places the phenomenon against the background of (increased) exchange: cultural, commercial and political. Such exchanges, he argues, were eased by the idea that one could translate one's deities into the languages of other peoples, since this made them recognizable, "comparable and contactable". ${ }^{31}$

Our examined dedications were presented in the Greek island of Delos, by non-Greeks (among them Phoenician businessmen) who offered worship to a combination of Greek and foreign deities. This certainly places them in a context where the possibility of religious translations might be helpful. If, however, the dedicators of the three Delian inscriptions had wished to make a visible translation between two or more gods, their easiest option would of course have been to carve a bilingual inscription. As examples of this can be taken another inscription from Delos, where Zeus Ourios is directly translated into Latin as Jupiter Secundanus (IDélos 1754), and a fourth-century Koan inscription, where Aphrodite is translated in Phoenician as Astarte, SEG 36, 758. ${ }^{32}$ The dedicators of my case inscriptions IDélos 1719, 2132 and 2305 chose not to do this and presented an allGreek text. But perhaps we should see the double gods of our three examined inscriptions as translations anyway, translations that simply exclude the foreign language text? I certainly argue that the juxtaposed names should be understood as approached by the dedicators as single recipient deities, but, again, should we understand these composites as divinities in their own right? Perhaps not. I propose the possibility that the examined case studies are attempts by three non-Greek dedicators to present their non-Greek recipient deities to the mainly Greek audience of the Delian sanctuary: an interpretatio Graeca made not by, but for Greeks. ${ }^{33}$ This suggestion is surely valid for the dedications mentioning Astarte Palaistine Aphrodite Ourania, since these votives without any doubt were made by non-Greeks (Phoenicians of Ascalon). The identity of the third dedicator is less clear, but it is highly possible that he also was a foreigner. If we accept Mora's 
hypothesis, he could have been a Syrian who had taken a Greek name, or, a Greek of the Eastern realm. ${ }^{34}$ Alternatively, Stephanie Budin has proposed that this Andromachos came from Ptolemaic-occupied Cyprus, with its Phoenician-influenced religious climate. ${ }^{35}$ Marie-Françoise Baslez and Corinne Bonnet both believed that the dedicator came from Sidon. ${ }^{36}$

The first dedicator is a well-known character. Philostratos was an active tradesman and banker in Delos (c. 140-98 B.c.E.), who eventually received the citizenship of Naples. ${ }^{37}$ The second worshiper of Astarte Palaistine Aphrodite Ourania is Damon, son of Demetrios, of whom we know only what he tells us in his dedication: he was once saved from pirates. Philostratos' dedication is dated c.100 B.C.E., and Damon's to the late second century B.C.E. ${ }^{38}$ Philostratos' altar was found in the Sanctuary of the Gods of Ascalon, a sacred area apparently to a large extent funded by Philostratos himself. It was situated on the northeastern slope of Mount Kynthos, in the vicinity of other sanctuaries of foreign deities, such as the Syrian sanctuary and the various sanctuaries and temples of the Egyptian gods. Damon's altar was found further away, but the piece is believed originally to have come from the Sanctuary of the Gods of Ascalon. For its original location, it is pertinent that the instructions for sacrifices on Damon's altar, i.e. that it is unlawful to offer goat, pig and cow, ${ }^{39}$ are similar to the ones carved on the altar of Poseidon of Ascalon, also discovered in the Sanctuary of the Gods of Ascalon, and thought to belong "in pair" with the altar to Astarte Palaistine Aphrodite Ourania erected by Philostratos..$^{40}$ This second altar of Philostratos' retains the exact same wording as IDélos 1719, except for the recipient deity; Philostratos dedicated it for the benefit of the city of Ascalon, himself and his wife and children, but as a dedication to Poseidon Ascalonites.

It appears that Philostratos and Damon alike expected mostly non-Phoenicians to read their inscriptions. They did not place their votives in a sanctuary where only their fellow Ascalonites would have come, as indicated by many features of their inscriptions. Firstly, they present their inscription in Greek only. Secondly, they present themselves with an ethnic, thus defining themselves as foreigners. This was not often the case when Phoenicians established the worship of their own gods abroad. In the most well known instances, they would celebrate their cults on grounds set apart by concession, with their own clergy, and where it would thus be superfluous to present oneself as Phoenician. ${ }^{41}$ Thirdly, they use precise epithets, something that was generally avoided by Phoenicians abroad. In fact, Philostratos and Damon interestingly follow the local custom of employing specific bynames, but all the while stressing the foreign character of their gods through these very same epithets: they underline the foreign geographic origin of the god/cult: of Palaistine for Astarte, and of Ascalon for Poseidon. ${ }^{42}$ The foreign origin of their goddess is thus (uniquely) stressed, ${ }^{43}$ while simultaneously she is presented in a Greek way, in Greek and thus presumably to a Greek or heavily hellenized audience. At the same time, the dedications were set up in a place with Oriental sacrificial regulations. ${ }^{44}$ Why?

13 Educated and travelling Greeks were familiar with the idea that Aphrodite Ourania was the Greek name of Astarte of Ascalon at least since Herodotos' writings. ${ }^{45}$ If they had wished for a direct translation, Philostratos and Damon could thus have contented themselves simply with the Greek name of Aphrodite Ourania, just as they did with Zeus Ourios or Poseidon of Ascalon; apparently they considered the Greek to suffice for the male gods. Alternatively, they could have contented themselves with only the transliterated name of Astarte. Phoenician deities who held proper names usually 
retained these when worshiped abroad, by foreigners and Phoenicians alike, and we know for example of a Koan thiasos combining Zeus and Astarte. ${ }^{46}$ It thus appears that, for some reason, Philostratos and Damon explicitly wanted a double intercultural denomination for Astarte/Aphrodite. In my opinion, the dedications were made to Astarte, the mistress of Ascalon and protectress of her seafaring worshipers in the diaspora and the combination of the two goddesses expresses exactly this. Of the two juxtaposed deities, Astarte is mentioned first, which in dedicatory language usually means that she is the more important deity. ${ }^{47}$ Then why add the name of the Greek goddess? As noted above, the primary audience (apart from the gods) were Greeks and the Hellenized community present in Delos. Therefore the dedicators used the usual translation of Astarte: Aphrodite Ourania. But this again begs the question, why was it necessary to inscribe the name of Astarte as well, when only a Greek designation was considered necessary for her partner, Zeus Ourios? ${ }^{48}$ I believe that the dedicators felt the need to make an explicit mention of Astarte's name for the sake of clarity. If only Aphrodite Ourania had been designated as recipient, in this particular dedicatory context, she is likely to have been understood exclusively as the Greek goddess of that name, certainly so when worshiped side by side with a second Greek god. However, the Greek Aphrodite Ourania did not exactly match the deity the Phoenicians wished to honour. It is likely that Philostratos and Damon knew that the Greek cult of Aphrodite Ourania did not (or did no longer) correspond well to the cult of their city protectress. Our examined dedications were erected in a Delos dominated by Athens. Aphrodite Ourania was an important deity in the latter city. Just like Astarte, she had significant political aspects, but, as clearly demonstrated by V. Pirenne-Delforge, from the Classical period onwards, the Athenian Ourania was mainly connected to marriage and fecundity. ${ }^{49}$ This dominating aspect had furthermore placed Ourania's marine aspects, the mythological connotations of Aphrodite's marine birth and subsequent voyage, somewhat in the background. This is seminal, because the cult of Astarte in and outside of Phoenicia had strong marine connotations. ${ }^{50}$ Thus, the straight-up translation Aphrodite Ourania would not have presented to the designated audience of Greeks and Hellenized Phoenicians what the dedicators wanted to convey. Ourania on her own would in the Delian-Athenian context have evoked too strongly the important marriage goddess, both if presented in the Greek section of a bilingual text or on her own in an all-Greek dedicatory inscription. But at the same time, Damon and Philostratos did wish to explain the character of their Astarte, who was perhaps not enough well known to stand alone. Thus, only through a combination of the two goddesses could the dedicators express with exactitude which deity they wanted to honour: Astarte, the Palaistinian one, who is like (but not identical to) the Aphrodite specified as Ourania. I suggest that in these two inscriptions, the double god Astarte Palaistine Aphrodite Ourania is not a (new) syncretistic god, but an intercultural translation. This translation functions on two levels. On the one hand, the entire denomination is a translation into Greek of the specific goddess honoured. But on the other hand, Aphrodite Ourania also translates Astarte. Because the inscription is not bilingual and thus not separated into a Phoenician text mentioning Astarte and a Greek one mentioning Aphrodite, any beholder is forced to read the names of Astarte and Aphrodite together. This means that while the name of Aphrodite Ourania translates Astarte into a divinity familiar to the Greeks, it simultaneously allows her (Astarte) to retain a clear foreign character, because of the oriental connotations of Ourania. By not mentioning Aphrodite Ourania alone, but in combination with Astarte, attention is led away from the Athenian nuptial goddess and towards the international understanding of 
Aphrodite Ourania as Astarte of Ascalon, something which in turn cleverly directs the audience's attention mainly to the first-mentioned goddess. ${ }^{51}$ Furthermore, through the addition of a second recipient deity with safety at sea as a speciality, Astarte and Aphrodite's marine aspects are put to the fore; they meet and activate, as it were, this power in each other. Zeus Ourios, Zeus of the Fair Wind, further reinforces the marine qualities of this dedication. ${ }^{52}$ In this way, in a language clear to all Greek-speaking visitors, the double denomination shows the recipient goddess to be firstly the mistress of Ascalon, the ancestral god and protectress of Philostratos and Damon, sheltering her protégés in the land of Ascalon/Palestine, and, through Astarte's and Aphrodite's added marine qualities, also on whatever voyage they would tempt. The double denomination is thus a translation, but not a straightforward interpretatio. As Bikerman has noted, often what appears to be an identification, is rather an explanation or interpretation of a foreign phenomenon..$^{53}$

The same Graeco-Phoenician ambiguity is visible in the name of one of the dedicators himself. Philostratos is obviously a Greek, not a Phoenician name. However, it is in this case also a Greek version of a Phoenician theophoric name formed from Astarte: for presentation in a Greek context, Phoenicians carrying the goddess' name often chose Greek names including STRAT- as equivalents, because of the acoustic resemblance with Astarte.$^{54}$ This is also of relevance for the interpretation of the double recipient god. The idea that there is not a full equivalence between Astarte and Aphrodite, that the devotion is pointed to Astarte in this case, is corroborated by Philostratos' choice of how to present himself in the Greek world. Should he have wanted to express exclusive devotion to Aphrodite, or wanted a complete translation equating Astarte and Aphrodite, he could have used the name Aphrodisios for himself. This name was in fact popular in Ascalon and Sidon, ${ }^{55}$ but it was rare for Phoenicians abroad, and as Baslez points out, this suggests that Astarte was not systematically identified with Aphrodite. ${ }^{56}$ This background corroborates the suggestion that the recipients of Philostratos' and Damon's dedications were deities of a fine-tuned character. A straightforward translation of one goddess into the other seems unlikely. However, neither is the complex Astarte Aphrodite a new syncretistic god with one heightened, intensified, power, as was the case with Isis Aphrodite, nor has one goddess wholly assimilated the other to form a new version of herself. What we encounter on the stones from the Sanctuary of the Gods of Ascalon is a presentation, translated to the Hellenized world, of the Phoenician goddess Astarte of Ascalon and of her relationship with the devotees that left their home city.

\section{An intriguing divine couple: Isis Soteira Astarte Aphrodite Euploia Epekoos and Eros Apollon Harpokrates, IDélos 2132}

The third and most intricate inscription remains to be discussed, the dedication presented to Isis Soteira Astarte Aphrodite Euploia Epekoos and Eros Apollon Harpokrates. Rather than a straightforward equivalence Isis=Astarte=Aphrodite, or a triple cross-cultural new deity, I am inclined to understand this votive inscription in the same way as the two previous, i.e., as a translated presentation of a foreign goddess, expressed through goddesses of other cultures, which thus allow certain qualities to become articulated. What is problematic here is of course that the ethnic identity of the dedicator, crucial to the previous argument, is missing. If one takes the clue from the 
inscription itself, a Syrian dedicator is not likely to stand behind the dedication, since there is in fact no Syrian element present. Aphrodite is not called Hagne or Syrian, nor is Atargatis herself present. ${ }^{57}$ Moreover, there are no known examples of a mix between Syrian and Egyptian cults in Delos. ${ }^{58}$ The Phoenician Astarte, however, is present in the inscription. Starting with the female composite, it is noteworthy that Astarte is the only deity who appears to be presented without an epithet. Is this an indication of her supremacy over the other goddesses, who are presented in more restrained aspects? And would that suggest a Phoenician origin or at least influence of the dedicator? Perhaps, but this would then be done in the shadow of the fact that there are Egyptian gods present in both the male and female composite. As noted above, one god usually seems to be the main one in a composite, and it is typically the first god mentioned. ${ }^{59}$ Astarte is for example placed before Aphrodite in the Ascalonites' inscriptions. By analogy, in the third inscription, where Isis is named before Astarte, she would then be the main deity, with the other goddesses guiding the beholder of the inscription and perhaps pinpointing the aspect that the dedicator identifies as uniting the three in the context of his dedication. The great international popularity of Isis makes it difficult to even speculate on the ethnical identity of the donor. Some suggestions on the character of his composite deity might however be made, since on a general level, the three goddesses have many things in common. The epithets then indicate more clearly what is at stake. Isis Soteira is the starting point, and this leads me to suggest that the entire complex of goddesses shows the recipient deity as a marine protectress. Isis with the admittedly broad epithet Soteira is often thus understood and Astarte and Aphrodite Euploia both translate and reinforce this quality, as it is expressed in the context of Phoenician and Greek culture respectively. ${ }^{60}$ The remaining epithet Epekoos is difficult to place. Does it belong to the combination of goddesses or only to Aphrodite? We cannot know, but either way, it underlines the performative behaviour of a goddess who listens and actively intervenes in the life of her worshipers. ${ }^{61}$

Above I did not much comment on the partner of Damon's Astarte Aphrodite, Zeus Ourios, since this god is not a composite figure, but the well-known Greek deity Zeus of the Fair Wind. But in IDélos 2132, we meet Isis Astarte Aphrodite in the company of a male composite: Eros Harpokrates Apollon. This is, if possible, an even more complicated symbiosis than the examined goddesses, since the characters do not have apparent functional affinities, nor do they correspond in any obvious way to the tripartite partner goddess. The Phoenician element is missing and the Greek component doubled. It has been suggested that the youthful gods Eros and Harpokrates are identified with each other, and that Apollon is present as a tribute to the Delian context. ${ }^{62}$ This is not necessarily the case. Harpokrates and Apollon were associated outside of Delos; in epigraphic sources the combination has been identified in Philippi, Thessaloniki and Naples. ${ }^{63}$ In the light of these inscriptions, a radical solution to the strange presence of Eros in IDélos 2132 would be that it is in fact a mistake for Horus, who is actually present in the mentioned non-Delian Harpokrates-Apollon inscriptions. ${ }^{64}$ However, it seems somewhat strange that what is most likely a one-time combination, such as Isis Soteira Astarte Aphrodite Euploia Epekoos, would be matched by what appears to have become an established combination. Moreover, this solution does not provide us with a Phoenician god, in parallel with the Egypto-Phoenician-Greek female composite. Since the reading is quite clear, we probably do better in leaving Horus behind and trying to understand what is actually to be seen on the stone. A possible interpretation of the 
combination Eros-Harpokrates-Apollon would be a functional complex, like the accompanying female one. This complex does not seem to underline a matching marine concern. Instead, I suggest that filial or mother-child relations could be the joining factor. ${ }^{65}$ Looking at the divine couples of IDélos 2132, we find two mother-son couples; Harpokrates is the son of Isis, Eros the son of Aphrodite. Leto is not present in the female triple god, but we must not forget the Delian context, where Apollon was often articulated as a son and a brother, within the Leto-Artemis-Apollon triad or together with his sister. ${ }^{66}$ IDélos 2132 was a thank-offering made for the benefit of the dedicator's wife and children and thus the family context could be of relevance for the understanding of the divine complexes. Certainly, this suggestion does not present complete coherence among the combined deities. Besides Leto, a son of Astarte is missing, and perhaps one would have expected Harpokrates to be the divine name first mentioned, in accordance with the placing of Isis.$^{67}$ Obviously, this interpretation remains a tentative suggestion, since the male trio of gods does not include epithets to indicate a specific character and the dedicator choose not to state a specific reason for his thank-offering.

\section{Conclusion}

17 The focus of the present article has been to investigate whether the three examined divine juxtapositions do create syncretistic gods, i.e., new entities born through the act and will, through the agency of a worshiper. Certainly, an ambiguity will always remain, in that the recipient deities are one and many, new and old. However, in conclusion I would like to argue that no, they are not new syncretism deities, because the gods are used to explain one another. I believe that what is at stake, rather than syncretistic gods, are dedicators behaving in a syncretistic manner, in the syncretistic milieu of Hellenistic Delos. The dedicators are consciously using their knowledge of various cultures in interaction, and they are communicating in terms to be intelligible to as many as possible, gods and humans alike. In this they are acting in a way that fits well with the functioning of a syncretistic system as identified by Martin, who sees Hellenistic syncretisms as "systemic relationships of resemblance construed in terms of sympathy and antipathy". ${ }^{68}$ Our three Delian dedicators have surely found a good way of creating divine alliances, lining up resembling gods from different cultures to care for their specific situations. ${ }^{69}$

\section{NOTES}

1. Hera Aphrodite: Pausanias, III, 13, 9. See also C. BonNET, V. PIRENNE-DELforge, "Deux déesses en interaction: Astarté et Aphrodite dans le monde égéen", in A. MOTTE, C. вONNET (eds.), Les syncrétismes religieux dans le monde méditerranéen antique, Bruxelles/Rome, 1999, p. 249-273, esp. p. 266-268. A dedication to Hera Aphrodite found in Akoris, Egypt, has been interpreted as an interpretatio Graeca of Hathor: BE 1990, no. 824; SEG 38, 1678. Zeus Ares: IG V 2, 343 = IPArk 15. For the phenomenon in general, see R. PARKER, “Artémis Ilithye et autres : le problème du nom divin 
utilisé comme épiclèse," in N. BELAYCHE et al. (eds.), Nommer les dieux. Théonymes, épithètes, épiclèses dans l'Antiquité, Turnhout, 2005 (Recherches sur les rhétoriques religieuses, 5), p. 219-226.

2. Isis Aphrodite: IDélos 2040, 2080 and $2158=$ L. BRICAULT, Recueil des inscriptions concernant les cultes isiaques (RICIS), Paris, 2005, vol. I, nos. 202/0346, 202/0322 and 202/0350; Amathous, Cyprus: SEG 38, 1501; Perinthos-Herakleia: RICIS 114/0601; M.H. SAYAR, Perinthos-Herakleia (Marmara Ereğlisi) und Umgebung. Geschichte, Testimonien, griechische und lateinische Inschriften, Vienna, 1998 ( Österreichische Akademie der Wissenschaften, Wien, Philosophisch-historische Klasse. Denkschriften, 269), no. 42 and perhaps from Egypt (Abu el-Matamir): A. BERNAND, Le Delta Égyptien d'après les textes grecs I, 4: La Béhéra Méridionale, Cairo, 1970 (Mémoires publiés par les membres de l'Institut français d'archéologie orientale du Caire, 422), p. 925-928.

3. IDélos 1719, 2132 and 2305.

4. IDélos 1719 and 2305.

5. IDélos 2132.

6. C. BONNET, "Le roi et la déesse. À propos de la dédicace grecque à Ptolemée et Aphrodite de la grotte de Wasta, près de Tyr," Studi Epigrafici e Linguistici sul Vicino Oriente Antico 21 (2004), p. 125140. Cf. F. DUNAND, Le culte d'Isis dans le bassin oriental de la Méditerranée I-III, Leiden, 1973, vol. II, p. 110.

7. P. PAKKANEN, Interpreting Early Hellenistic Religion, Helsinki, 1996 (Papers and Monographs of the Finnish Institute at Athens, 3), p. 89-92.

8. P. LÉVÊQUE, “Essai de typologie des syncrétismes," in F. DUNAND, P. LÉVÊQUE (eds.), Les syncrétismes dans les religions grecque et romaine, Paris, 1973 (Bibliothèque des centres d'études supérieures spécialisés; Travaux du Centre d'études supérieures spécialisé d'histoire des religions de Strasbourg), p. 179-187.

9. A. MOTTE, V. PIRENNE-DELFORGE, “Du « bon usage » de la notion de syncrétisme," Kernos 7 (1994), p. 11-27.

10. MOTTE, PIRENNE-DELFORGE, l.c. (n. 9), p. 18.

11. L.H. MARTIN, "Why Cecropian Minerva? Hellenistic Religious Syncretism as a System," Numen 20 (1983), p. 131-145. Recent studies on polytheism call for an acceptance of what may seem "chaotic" to us, since the Greeks themselves apparently did not find an infinite amount of gods, contradictory accounts of their competences and actions etc., much of a problem, see for example R.PARKER, "The Problem of the Greek Cult Epithet", OpAth 28 (2003), p.173-183; H.S. VERSNEL, Coping with the Gods. Wayward Readings in Greek Theology, Leiden, 2011.

12. Inv. E 815 . Height $0.75 \mathrm{~m}$, diam., $0.75 \mathrm{~m}$. It was found in the so-called Sanctuary of the Gods of Ascalon. It should be noted that the sanctuary is thus named in part because of this inscription.

13. For the dedicator, see also IDélos 1717-1718, 1720-1724. For a discussion of many aspects of the complex relationship between Aphrodite and Astarte, see BONNET, PIRENNE-DELFORGE, l.c. (n. 1). 14. The significance of word order in dedicatory language will be further discussed below.

15. Zeus Ourios in Delos: IDélos 1754, 2415 and 2416; the editor notes that he was often associated to the Egyptian and Oriental gods: IDélos 2127, 2179. For the Hellenistic cults of Delos in general, see the still important Ph. BRUNEAU, Recherches sur les cultes de Délos à l'époque hellénistique et à l'époque impériale, Paris, 1970 (BEFAR, 217). For Bruneau's comments on the inscriptions treated in this article, see p. 346-348.

16. Inv. E 28. Height $0.53 \mathrm{~m}$, diam. 0.41 , found close to the southern wall of the Salle Hypostyle. In Latin, Zeus Ourios was called Jupiter Secundanus, IDélos 1754, 1. 7 and 21.

17. By a single deity, I wish to refer to an integrated entity. This entity may originally have consisted of (in this case) two separate gods, or may feature associated divine powers, what matters here is that two gods are treated as one recipient deity. The gods approached in ID 1719 are not Zeus Ourios, Astarte Palaistine and Aphrodite Ourania, but Zeus Ourios and Astarte Palaistine Aphrodite Ourania. 
18. Ch. CLERMONT-GANNEAU, "Une dédicace à Aphrodite Palestinienne, découverte à Délos," CRAI 53 (1909), p. 307-317. This was later rectified by the editor, in Ch. CLERMONT-GANNEAU, "Dédicace à l'Astarté palestinienne : rectificatif," CRAI 54 (1910), p. 412-413.

19. In the context of the gymnasium, dedications were often presented to Hermes and Herakles, thus, an editor would hardly present Hermes Herakles of IDélos 1933 as a composite god, although the layout does not separate them visually on the stone, as in IG XII 7, 424, for example.

20. Inv. E 425 . Height $0.85 \mathrm{~m}$, lenght $0.63 \mathrm{~m}$, width $0.57 \mathrm{~m}$. See also P. ROUSSEL, Les cultes égyptiens à Délos du II au ire siècle av. J.-C., Paris, 1916, p. 196, no. 194.

21. F. MORA, Prosopografia Isiaca 1. Corpus prosopographicum religionis isiacae, Leiden, 1990, p. 60, no. 12; RICIS 202/0365.

22. The first goddess is epigraphically attested in various places in the Greek world, and a wellknown type in iconography. Isis Demeter is to my knowledge not attested in inscriptions, but the coalition is well defined in other sources, not least in iconography: PAKKANEN, o.c. (n. 7); P. PACHIS, “"Manufacturing religion" in the Hellenistic age: The Case of the Isis-Demeter Cult," in L.H.MARTIN, P.PACHIS (eds.), Hellenisation, Empire and Globalisation: Lessons from Antiquity, Thessaloniki, 2004, p. 163-207. For Zeus Ammon, see for example Pindaros, Pyth. 4. For Isis Aphrodite, supra n. 2; J. WALlensten, "Personal Protection and Tailor-made Epithets," Kernos 21 (2008), p. 81-95.

23. Again, I stress that a dedication to Isis Aphrodite is thus not presented to the two goddesses Isis and Aphrodite, or Aphrodite and Arsinoë, but to a single recipient, which thus appears as an integrated deity. For various aspects of the worship of Aphrodite Arsinoë/Aphrodite Arsinoë, see for example P.M. FRASER, Ptolemaic Alexandria I, p. 197, 239-246; K. GUTZWILlER, “Callimachus' Lock of Berenice: Fantasy, Romance, and Propaganda," AJPh 113 (1992), p. 359-385; K. GUTZWILLER, "The Nautilus, the Halcyon, and Selenaia: Callimachus "epigram" 5 Pf=14 G.-P.", ClAnt 11 (1992), p. $194-$ 209; E. CARNEY, "The Initiation of Cult for Royal Macedonian Women", CPh 95 (2000), p. 21-43; S. BARBANTANI, "Goddess of Love and Mistress of the Sea. Notes on a Hellenistic Hymn to ArsinoëAphrodite," Ancient Society 35 (2005), p. 135-165; s. CANEVA, "Queens and Ruler Cults in Early Hellenism: Observations on Festivals, and on the Administration and Ideological Meaning of Cults", Kernos 25 (2012), p. 75-101; E. CARNEY, Arsinoë of Egypt and Macedon. A Royal Life, Oxford/New York, 2013, esp. p. 98-100, 101. It can be noted that the goddess is referred to sometimes as Aphrodite Arsinoë, sometimes Aphrodite Arsinoë, and there is no consensus as to which term to use when describing the relationship between the goddess and the queen: "identification", "assimiliation" and "association" are all used. This is clearly an important and interesting case that would profit from a pointed study.

24. MOTTE, PIRENNE-DELFORGE l.c. (n. 9), p. 18; J. ASSMANN, "Translating Gods: Religion as a Factor of Cultural (Un)Translatability", in S. BUDICK, W. ISER (eds.), The Translatability of Cultures. Figurations of the Space Between, Stanford, 1996, p. 34.

25. IPerinthos 42: a former priest presented a dedication to Isis Aphrodite. The divine names appear without a kai between them, but each was carved on a line of its own. The inscription thus further illustrates the problem examined and enhances the importance of examining each inscription in context. The editors however believe the priest to be of Isis-Aphrodite and date the inscription 3rd-2nd century B.C.E.

26. WALLENSTEN, l.c. (n. 22).

27. Perhaps one could even understand a heightened power as regards the aspect in question. 28. AsSMANN, l.c. (n. 24), p. 34: "The local identities are not altogether abolished; they are only made transparent, as it were." An "international divine alliance" would perhaps be another pertinent term to describe this outcome. See furthermore PARKER, l.c. (n. 1), p. 225: juxtaposition of two divine names does not always mean identification or assimilation, but see also Fraser o.c. (n. 23), p. 245 who refers to Aphrodite Akraia Arsinoë as an "identification by juxtaposition". 
29. PARKER, l.c. (n. 1), p. 223-225.

30. E. BIKERMAN, “Anonymous Gods”, Journal of the Warburg Institute, 1.3 (1938), p. 187-196; J.ASSMAN, Moses the Egyptian. The Memory of Egypt in Western Monotheism, London/Cambridge, Mass., 1997, p. 44-54; l.c. (n. 24), p. 25-36; M.s. SMITH, God in Translation. Deities in Cross-Cultural Discourse in the Biblical World, Grand Rapids, Mich. / Cambridge, 2010, esp. p. 243-273; G. FOWDEN, The Egyptian Hermes. A Historical Approach to the Late Pagan Mind, Princeton, NJ, 1993, esp. p. 45-74. I am very grateful to the anonymous Kernos reviewer who introduced me to this fascinating discussion.

31. ASSMAN, o.c. (n. 30 ), p. 45; l.c. (n. 24), p. 27-28.

32. See also SEG 39, 852; SEG 41, 1800; SEG 49, 1119 bis and SEG 55, 936; SEG 57, 771. For another bilingual dedication found in Kos, made by a Nabaetean and honouring Aphrodite (rendered as Ba'ala in Nabatean), see M. SEGRE, Iscrizioni di Cos, Rome, 1993 (Monografie della Scuola Archeologica di Atene e delle Missioni Italiane in Oriente, 6): EV 259; G. LEVI DELLA VIDA (with a note by M. Segre), "Una Bilingue Greco-Nabatea a Coo", Clara Rhodos 9 (1938), p.139-148. Bilingual Greek-Semitic inscriptions have been found in many places around the Mediterranean: Malta, Cyprus, Athens, Miletos and Rhodes, for example; see P.M. FRASER, "Greek-Phoenician Bilingual Inscriptions from Rhodes", ABSA 65 (1970), p. 31-36. The earliest (Babylonian) translations of divine names appear in lists, giving the corresponding names in two or more languages, ASSMAN, l.c. (n. 24), p. 25-26.

33. Less elaborate examples of this can perhaps be found in the context of the Egyptian cults in Delos. Roussel suggested that these divinities quite often were presented by his or her Greek and Egyptian name, as for example in IDélos 2135, presented to Sarapis, Isis, Anoubis Hermes and Apollon Harpokrates (the dedicator is an Alexandrian): Roussel, o.c. (n. 20), p. 97-98, no. 18. See also ASSMANN, l.c. (n. 24), p. 35 on the interpretatio Graeca of Egyptian gods as an Egyptian conception.

34. MORA, o.c. (n. 21), p. 12, no. 60.

35. S.L. BUDIN, "A Reconsideration of the Aphrodite-Ashtart Syncretism," Numen 51 (2004), p. $95-$ 145. She considers the combination of gods as created through consideration of the political milieu of Cyprus and proposes that during the Ptolemaic occupation there was "a need to recognize the Greek/Cypriot, Phoenician/Cypriot, and Egyptian pantheons" (p. 131).

36. M.-F. BASLEZ, "Cultes et dévotions des phéniciens en Grèce : les divinités marines," in C. BONNET, E. LIPINSKI, P. MARChetTI (eds.), Religio Phoenicia, Namur, 1986 (Studia Phoenicia, 4), p. 289-305; C. BONNET, Astarté. Dossier documentaire et perspectives historiques, Rome, 1996 (Contributi alla storia della religione fenicio-punica, 2). BASLEZ, l.c., p. 291, and BONNET, o.c., p. 87 furthermore calls the dedicator a Sidonian woman. Has there been a mix-up between IDélos 2132 and IDélos 2101? The latter was however made by a man, Dionysios of Sidon. Hiller von Gaertringen believed the dedicator to be a Delian citizen: Syll. ${ }^{3} 1132$, however, this has not been accepted by The Lexicon of Greek Personal Names, who lists Andromachos as "attested in Delos": LGPN I, Andromachos no. 9.

37. J. ANDREAU, Banking and Business in the Roman world, Cambridge, 1999, p. 49; K. LOMAS, Roman Italy, 338 BC-AD 200. A Sourcebook, London/New York, 1996, p. 68.

38. BUDIN, l.c. (n. 35), p. 130.

39. I thank Dr. Maria Patera for the interesting suggestion that the regulations might not be sacrificial, but referring to the prohibition of bringing to the sanctuary anything made of (the skins of) goat, pig and cow (personal communication); see also M. PATERA, "Ritual Dress Regulations in Greek Inscriptions of the Hellenistic and Roman Period," in K. vössING, S. SCHRENK (eds.), Kleidung und Identität in religiösen Kontexten der römischen Kaiserzeit, Mannheim, 2012 ( Mannheimer Geschichtsblätter).

40. IDélos 1720; J. MARCADÉ, "La pseudo-signature de Nikandros d'Andros, à Délos," BCH 73 (1949), p. 152-157, esp. p. 155; LSS 55, 58; NGSL 58. It can furthermore be noted that the editor of LSS, F. Sokolowski, separates Aphrodite Ourania and Astarte as two different goddesses. 
41. BASLEZ, l.c. (n. 36), p. 293.

42. BASLEZ, l.c. (n. 36), p. 293-295. Phoenicians abroad avoided restricted epithets, such as for example Ourania for the goddess of Kition (p. 294-295); BONNET, o.c. (n. 36), p. 88.

43. BONNET, o.c. (n. 36), p. 88.

44. LSS 55, 58; NGSL, p. 58.

45. Herodotos, I, 105; BONNET, o.c. (n. 36), p. 89. It is moreover usually assumed that Astarte hides behind the Aphrodite worshiped by the merchants of Kition in the Pireus, IG II ${ }^{2}, 337$, see for example S. PRICE, Religions of the Ancient Greeks, Cambridge, 1999, p. 76; B. BREITENBERGER, Aphrodite and Eros. The Development of Erotic Mythology in Early Greek Poetry and Cult, New York/London, 2010, p. 13. On the relationship and interactions between Aphrodite and Astarte, see BONNET, PIRENNEDELFORGE, l.c. (n. 1), p. 249-273.

46. BIKERMAN, l.c. (n. 30), p. 188, 194; SEGRE o.c. (n. 32), no. EF 202; A. MAIURI, Nouva silloge epigrafica di Rhodi e Cos, Florence, 1925, no. 496.

47. PARKER, l.c. (n. 1), p. 226; BIKERMAN, l.c. (n. 30), p. 190.

48. As Prof. Robert Parker points out to me, it is indeed puzzling that Zeus Ourios is not given a Phoenician name, as part of a worshiped divine couple. Is Zeus and Astarte possibly a reoccurring, if not well-established, couple, with a marine Baal hiding behind the name of Zeus? See once again SEGRE, o.c. (n. 32), no. EF 202; MAIURI, o.c. (n. 46), no. 496; BONNET, o.c. (n. 36), p. 87. To my mind, the name Astarte attracts even more attention against the background of the two Greek names.

49. V. PIRENNE-DELFORGE, "Des épiclèses exclusives dans la Grèce polythéiste? L'exemple d'Ourania," in BELAYCHE et al. (eds.), o.c. (n. 2), p. 271-290, esp. p. 280-282; SEG 41, 182; v. PIRENNEDELFORGE, L'Aphrodite grecque, Athènes/Liège, 1994 (Kernos, suppl. 4), p. 15-25. For Ourania outside of Athens, see PIRENNE-DELFORGE, ibid;; BONNET, PIRENNE-DELFORGE, l.c. (n. 1); y. ustinova, “Aphrodite Ourania of the Bosporus: The Great Goddess of a Frontier Pantheon," Kernos 11 (1998), p. 209-226; Y. Ustinova, The Supreme Gods of the Bosporan Kingdom: Celestial Aphrodite and the Most High God, Leiden, 1999 (RGRW, 135); G. PIRONTI, Entre ciel et guerre. Figures d'Aphrodite en Grèce ancienne, Liège, 2007 (Kernos, suppl. 18), especially investigating and underlining the complex connections to Ouranos/Heaven, of Ourania.

50. BONNET, o.c. (n. 36), p. 88, 90. On Aphrodite's maritime aspects, see for example PIRENNEDELFORGE, o.c. (n. 49), p. 434-437; R. PARKER, "The Cult of Aphrodite Pandamos and Pontia on Cos," in H.F.J. HORSTMANSHOFF et al. (eds.), Kykeon. Studies in Honour of H.S. Versnel, Leiden, 2002, 143-160,

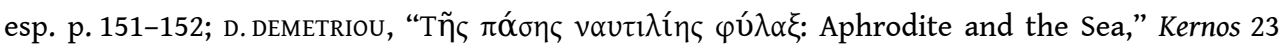
(2010), p. 67-86.

51. Cf. BONNET, PIRENNE-Delforge, l.c. (n. 1), p. 270; BONNET, o.c. (n. 36), p. 88, 89. For further comments on the importance of the first-mentioned deity, see below.

52. Judging by the epigraphic sources, Zeus and Aphrodite were quite often approached as a couple, see J. WALLENSTEN, forthcoming. The couple as saviours at sea: SEG 49, 1408, carved on an anchor, with the matching epithets $\sigma \omega \hat{\zeta} \zeta \omega v, \sigma \omega \hat{\zeta} \zeta o v \sigma \alpha$. For Zeus (Soter) as a translated Baal of the sea, see BONNET, o.c. (n. 36), p. 87. In these circumstances it should be underlined again that the choice of epithet for Aphrodite in IDélos 2305 was not a matching marine one, such as Euploia. The dedicator's choice of the epithet Ourania becomes even more eye-catching in this context. It is furthermore interesting to note the similarity in sonority between Ourios and Ourania.

53. BIKERMAN, l.c. (n. 30), p. 188.

54. BONNET, o.c. (n. 34), p. 90; BASLEZ, l.c. (n. 34), p. 300; O. MASSON, "Recherches sur les Phéniciens dans le monde hellénistique," BCH 93 (1969), p. 679-700, esp. p. 692; CLERMONT-GANNEAU, l.c. (n. 18), p. 310. This was not only a Phoenician habit. M.-F. BASLEZ, L'étranger dans la Grèce antique, Paris, 1984, p. 247 mentions the examples of the name Heliodoros as a substitute for the Arab Abd-el- 
Shamash (Servant of the Sun) and the name Mousaios used instead of the Jewish Moses. - I thank Prof. Jan Bremmer for suggesting to me that the choice of Greek names including a derivation of Strat- for Phoenician names stemming from Astarte might also mirror the martial character of Astarte; the acoustic resemblance was perhaps not the only factor involved (personal communication).

55. CLERMONT-GANNEAU, l.c. (n. 18), p. 310, n. 4; BASLEZ, l.c. (n. 36), p. 300.

56. BASLEZ, l.c. (n. 36), p. 300; BUDIN, l.c. (n. 35); BONNET, o.c. (n. 36), p. 90. The name does however exist for Phoenicians abroad. For an inscription found in Athens, translating the Phoenician "I am Shmr, son of Abd'štrt ("I am Shmr, Servant of Ashtart") as "Antipatros Aphrodisiou," see E.H. PALMER, J.E. SANDYS, “Athenian Bilingual Inscription,” The Journal of Philology 4 (1872), p. 48-51, esp. p. 48-49; BUDIN, l.c. (n. 35), p.129. For other examples of translated names, such as Herakleides for Abdelmelqart, see FRASER, l.c. (n. 32).

57. A. HAUVeTte-BeSnAult, "Fouilles de Délos: temple des dieux étrangers," BCH 6 (1882), p. 470 503, commented on the inscription that it appears to "completely identify Isis and the Syrian Aphrodite" (p. 473). See also BIKERMAN, l.c. (n. 30), p. 190, on the development Atargatis-Hagne Aphrodite and the implications of this name-change. For Mora's suggestion that the dedicator was from Antiocheia, see MORA, o.c. (n. 21), p. 60, no. 12. Naturally, that a Syrian deity is not included among the three goddesses does not necessarily exclude the possibility of a Syrian dedicator.

58. ROUSSEL, o.c. (n. 20), p. 132.

59. PARKER, l.c. (n. 1), p. 226; BIKERMAN, l.c. (n. 30), p. 190.

60. For Soteira as a marine protectress: BRICAULT, o.c. (n. 2), no. 204/0108; M.-F. BASLEZ, Recherches sur les conditions de pénétration et de diffusion des religions orientales à Délos (II $-I^{e r}$ s. avant notre ere), Paris, 1977 (Collection de l'École Normale Supérieure de jeunes filles, 9), p. 88; DUNAND, o.c. (n. 6), vol. III, p. 30; A.D. NOCK, Conversion: The Old and the New in Religion from Alexander to Augustine of Hippo, Oxford, 1933, p. 56.

61. It is perhaps also of interest to note that Soter/Soteira is used mostly for the Egyptian gods, and Epekoos for the oriental gods or by Oriental worshipers: BASLEZ, o.c. (n. 60), p. 132.

62. PAKKANEN, o.c., (n. 7), p. 90.

63. DUNAND, o.c. (n. 6), vol. II, p. 110; Philippi: RICIS 113/1002; P. COLLART, "Le sanctuaire des dieux égyptiens à Philippes," BCH 53 (1929), p. 70-100, esp. p. 77-79. Thessaloniki: RICIS 113/0525. Naples: INapoli I, no. 6 = IG XIV, 719 = RICIS 504/0301 = CIG 5793. This inscription was carved on a statue base and appears to have carried a statue of the three gods, presumably as one figure. Bricault (RICIS) thus believes that Apollon-Horus-Harpokrates was considered a single god in this latter inscription, in contrast to his nos. 113/0525 and 113/1002, where he believes HorusApollon is separated from Harpokrates. Apollon and Harpokrates are perhaps associated in another Delian inscription, IDélos 2135. For a dedication to Horus and Harpokrates, or HorusHarpokrates, see RICIS 113/0905. Unknown provenance combining the three gods: CIG 7045. See also ROUSSEL, o.c. (n. 20), p. 122, no. 72, p. 278.

64. The identification Apollon-Horus was done already by Herodotos, II, 144. See also collART, ibid.; IG X 2.1, 85.

65. On functional divine complexes, see J. WALLENSTEN, "Apollo and Artemis: Family Ties in Greek Dedicatory Language," in M. HAYSOM, J. WALLENSTEN (eds.), Current Approaches to Religion in Ancient Greece, Papers Presented at a Symposium at the Swedish Institute at Athens, Athens 17-19 April 2008, Stockholm, 2011, p. 23-40.

66. DUNAND, o.c. (n. 6), vol. II, p. 110; WALLENSTEN, l.c. (n. 66).

67. One must certainly agree with the Kernos reviewer that we often have to admit that we simply cannot know what lies behind the choice of recipient deities/divine designations.

68. MARTIN, l.c. (n. 11), p. 140. 


\section{ABSTRACTS}

In the Greek epigraphical corpus can be identified a number of dedications to what we might call composite, or double, deities, e.g., Isis Aphrodite. Related non-cross-cultural composites gods can also be found, such as Hera Aphrodite of Sparta, or Zeus Ares of Arcadia. The focus of this paper is however three cases where gods of different cultures are combined. I will primarily examine three elaborate examples, which include cult epithets. These case studies come from Hellenistic Delos: the paper discusses the twice attested goddess Astarte Palaistine Aphrodite Ourania (in one case further specified as Epekoos) and the once attested Isis Soteira Astarte Aphrodite Euploia Epekoos, a goddess joined in worship to the male mixture Eros Harpokrates Apollon. As might be expected, these deities have often been termed syncretistic gods and they have been discussed as the results of processes of parallelization, assimilation, identification, or even simply of translations of gods of one culture to those of another. The present paper examines this terminology and tries to characterize the divinities in question in a more specific way. I argue that perhaps rather than syncretistic gods, in these circumstances we should discuss the syncretistic behaviour of the dedicators and the syncretistic milieu in which they lived.

Dans les corpus épigraphiques grecs apparaissent des dédicaces à des divinités que l'on pourrait appeler « composites » ou « doubles », e.g. Isis Aphrodite. Des dieux « composites » internes à la culture grecque sont également attestés, comme Héra Aphrodite à Sparte ou Zeus Arès en Arcadie. L'objectif de cette étude est d'analyser trois cas où des dieux de cultures différentes sont combinés, en des exemples complexes qui incluent des épiclèses. Ces cas proviennent de la Délos hellénistique : Astarté Palaistine Aphrodite Ourania attestée deux fois (dans un des deux cas, elle est aussi Epekoos) et Isis Soteira Astarte Aphrodite Euploia Epekoos, une déesse cultuellement associée au regroupement masculin Éros Harpocrate Apollon. Comme on peut s'y attendre, ces divinités ont souvent été qualifiées de « syncrétiques » et conçues comme le produit de processus de mise en parallèle, d'assimilation, d'identification, ou même simplement de traduction de divinités d'une culture à l'autre. L'article examine cette terminologie et tente de caractériser ces divinités d'une manière plus spécifique. Il s'avère que, davantage que des "dieux syncrétiques ", nous devons plutôt aborder l'attitude «syncrétique » des dédicants et le milieu «syncrétique » dans lequel ils vivent.

\section{AUTHOR}

\section{JENNY WALLENSTEN}

Swedish Institute at Athens

Mitseon 9

GR - 11742 Athens

jenny.wallensten@sia.gr 